\title{
Studies on Population Dynamics of Sucking Pests Complex of Chilli and their Relation with Environmental Factors
}

\author{
P. Prathyusha*, R. K. Dwivedi, Deepak Pal and Gulab \\ Department of Entomology, College of Agriculture, Chandra Shekhar Azad University of \\ Agriculture and Technology, Kanpur-208002, U.P., India \\ *Corresponding author
}

\section{Keywords}

Chilli, population dynamics, sucking pest complex, correlation, environmental factors

\section{Article Info}

Accepted: 22 April 2021 Available Online: 10 May 2021

\section{A B S T R A C T}

The present experiment entitled Studies on population dynamics of sucking pests complex of chilli and their relation with environmental factors was carried out in Insectary, Department of Entomology, CSAUA\&T, Kanpur in kharif season 20182019. An experiment is conducted to find out the seasonal abundance of sucking pest complex of chilli. The presence of aphid, whitefly, and mites were recorded from the vegetative to maturity stage of the crop. Aphid, whitefly and mites were found to damage the crop moderately. First appearance of aphids were observed on $33^{\text {rd }}$ standard week and reached at its peak during $37^{\text {th }}$ standard week. The aphid population showed positive significant relation with maximum temperature and positive non significant relation with the minimum temperature, minimum relative humidity. Maximum relative humidity and rainfall are negatively non significant with aphid population. The occurrence of thrips on $35^{\text {th }}$ standard week and reached to peak on $44^{\text {th }}$ standard week. Maximum temperature showed non- significant positive correlation with thrips population. Minimum temperature have non-significant negative correlation. Remaining maximum and minimum relative humidity, rainfall showed negative correlation but statistically significant. Chilli mite was first appeared on $36^{\text {th }}$ standard week and it's at peak on $47^{\text {th }}$ standard week. Maximum and minimum temperature, maximum and minimum relative humidity, rainfall are negatively correlated to the mite population. Maximum temperature is non-significant while all other parameters are statistically significant.

\section{Introduction}

Chilli (Capsicum annum L.and Capsicum frutescenes) is an important spice cum vegetable crop belongs to family solanaceae. The native home of chilli is considered to be in Mexico. Nutritionally, it is rich source of
vitamin-A, B, C and $\mathrm{E}$ with minerals like molybdenum, potassium, and folate. Capsaicin $\left(\mathrm{C}_{18} \mathrm{H}_{27} \mathrm{O}_{3} \mathrm{~N}\right)$ is an alkaloid produced by chilli is responsible for its pungency and has medicinal properties to prevent heart attack by dilating the blood vessels. India is the largest consumer and exporter of chilli in the world 
with a production of 1492 thousand MT from an area of 775 thousand hectare (Ministry of Agriculture \& Farmers Welfare 2019-20). About 5-10 percent is exported in the form of chilli powder and oleoresins (Singhal, 2003). India contributes about $36 \%$ to the total world production. The major chilli growing states are Andhra Pradesh, Maharastara, Karnataka, Tamil nadu, Rajasthan, and in hill areas of Uttar Pradesh. In UP production of chilli is 12.72 thousand tons.

About 51 insects and 2 mite species belonging to 27 families and 9 orders infesting chilli (Reddy and Puttuswami, 1988). Among this aphid, Aphis gossypi Genn, whitefly, Bemesia tabaci, jassid, Amrasca biguttula biguttula, fruit borer, Helicoverpa armigera Hubner, mites, Polyphagotarsonemus latus are the important pests that contributing 50-90 per cent of yield loss out of which thirps, whitefly, and aphid cause major damage resulting in low productivity reducing up to $50 \%$ of yield (kumar, 1995). Thrips can alone cause economic loss upto 30-50 per cent (Bhede et al., 2008).

Thrips, mites and aphids causing leaf curl complex which is one of the most destructive syndrome affecting in chilli. Thrips and mite causing leaf curl syndrome called "mudra" complex in chilli (Venkatesh et al., 1998).

Mites attack the upper portions like young leaves and buds forming crumpled, rosette and the plant become stunted (karmakar, 1997). Leafs truns to dark green colour curled downwards and petiole is elongated. While in thrips damage leaves will be crinkled and curled upwards. While aphids suck sap and secrete honey dew which forms a black coating hinders photosynthetic activity of plant (Butani, 1976). A thorough Survey of seasonal incidence or population dynamics of thrips, mites, and aphids in chilli crop in relation to environmental factors helps in developing efficient pest management strategies in a particular set of agro climatic conditions. Basic information about the populations dynamics of insects is needed for the selection of proper method of control (Manjunath et al,. 2001).

\section{Materials and Methods}

An experiment is conducted in Insectary, Department of Entomology, CSAUA\&T, Kanpur in kharif season 2018-19. The chilli seedlings of variety Azad-1 was obtained from Vegetable Research farm, kalyanpur, Chandra Shekhar Azad University and Technology. About 550 seedlings are obtained and transplanted in the experimental plot $(2 \mathrm{~m} \mathrm{x}$ $1.5 \mathrm{~m})$. The infestation of aphid and thrips is measured by taking the readings from randomly selected 5 plants in a plot. Mite infestation is taken in percentage damage. In each plot five plants are randomly selected, in each plant three infested leaves, upper, middle and lower are selected (Bhatt and Karnatak, 2018). Each leaf is observed under the stereo zoom binocular microscope and the observations are recorded. Data collected in the morning hour at weekly interval right from vegetative to maturity stage of crop.

\section{Results and Discussion}

Weekly observations were recorded from transplanting to maturity of the crop. Studies on pest incidence were initiation from august 2018 and continued up to January 2019. Studies on insect pest succession and field incidence revealed that three species of insect sucking pests were observed to be associated with various stages of the chilli crop at Kanpur, Uttar Pradesh during 2018-19. The insect pest species associated with chilli crop along with their nature of damage, damaging stage, seasonal incidence and their relation with environmental factors have been studied and shown in table 1 and 2 . 
Sucking Pest complex on chilli crop succession at CSAU\&T, Kanpur

\section{Aphid}

First appearance of the pest in the field was observed $33^{\text {rd }}$ standard week of august 2018 and was available up to $52^{\text {nd }}$ standard week. The number of aphids were recorded weekly and reached its peak during $37^{\text {th }}$ week (22.93 aphids/ 3 leaves). The acquired results are at par with the findings of Meena R.S, O.P Ameta (2013). The aphid attained their peak population in first and second week of September during 2006-07 (9.0 aphids/ 3leaves/plant) and during 2007-08 (9.3 aphid/ 3 leaves/plant), respectively. Deepak kumar $e t$ al., 2019, observed that the aphid population attained it's on $44^{\text {th }} \mathrm{SW}$.

\section{Thrips}

First appearance of the pest in the field was observed $35^{\text {rd }}$ standard week of august 2018 and was available upto $52^{\text {nd }}$ standard week. The number of thrips were recorded weekly. Thrips population reached its peak on $42^{\text {nd }}$ week (8.33 thrips/3 leaves). These results, may be arranged with earlier findings of Patnaik et al., the incidence of chilli thrips was low from August to December and from May onwards a steady rise in the pest population to reaching its peak in December. Bhede et al.,2008, studied on population dynamics of chilli thrips, Scirtothrips dorsalis (Hood). They reported that incidence of thrips was highest during 40th meteorological week.

\section{Mites}

Chilli mite was first appeared on $36^{\text {th }}$ standard week of august 2018 and was available upto $52^{\text {nd }}$ standard week of august. The highest number of mite population was recorded on $47^{\text {nd }}$ week (12.41 mites/leaf). The obtained results are at par with Lingeri et al., studied the seasonal incidence of chilli mite, The peak activity of chilli mite was noticed in the months of November and February.

\section{Co-efficient of Correlation and regression equation of aphid abundance with environmental factors}

\section{Aphid}

Correlation studies revealed that maximum and minimum temperature, minimum relative humidity exhibited positive correlation $(\mathrm{r}=$ $0.46,0.40$, and 0.184 respectively) with aphid population, statistically maximum temperature is significant but minimum temperature and minimum relative humidity and are found to be statistically non significant. Further, maximum relative humidity, and rainfall showed a negative correlation $(r=-0.23$, 0.187 respectively) with aphid population, but statistically found to be non significant. The acquired results are at par with the findings of Ghose et al., 2018 recorded a positive correlation with minimum temperature, Rafee, 2018 showed that maximum temperature have positive correlation with aphid population.

\section{Thrips}

Correlation studies revealed that maximum temperature showed non- significant positive correlation $(r=0.30)$ with thrips population Minimum temperature have non-significant negative correlation ( $\mathrm{r}=-29)$, Remaining maximum and minimum relative humidity, rainfall showed negative correlation but statistically significant. The results are at par with, Reddy et al., 2017, recorded a negative correlation with minimum relative humidity. Patel et al., 2009, recorded a positive correlation with maximum temperature. 
Table.1 Abundance of insect-pests as affected by environmental factors on chilli crop

\begin{tabular}{|c|c|c|c|}
\hline \multirow[t]{2}{*}{ Standard week } & \multicolumn{3}{|c|}{ Mean number of insects on chilli } \\
\hline & Aphid/3 leaves & Thrips/3 leaves & Mite/leaf \\
\hline 31 & 0.00 & 0.00 & 0.00 \\
\hline 32 & 0.00 & 0.00 & 0.00 \\
\hline 33 & 5.42 & 0.00 & 0.00 \\
\hline 34 & 9.60 & 0.00 & 0.00 \\
\hline 35 & 16.50 & 1.26 & 0.00 \\
\hline 36 & 20.66 & 1.53 & 2.29 \\
\hline 37 & 22.93 & 3.26 & 2.73 \\
\hline 38 & 17.00 & 2.13 & 3.60 \\
\hline 39 & 14.20 & 3.90 & 5.81 \\
\hline 40 & 11.93 & 9.26 & 6.40 \\
\hline 41 & 8.63 & 6.66 & 5.94 \\
\hline 42 & 7.52 & 8.33 & 3.59 \\
\hline 43 & 12.16 & 7.07 & 4.70 \\
\hline 44 & 10.71 & 9.30 & 10.94 \\
\hline 45 & 10.41 & 6.36 & 7.61 \\
\hline 46 & 11.43 & 5.28 & $\mathbf{7 . 8 0}$ \\
\hline 47 & 7.71 & 4.66 & 12.49 \\
\hline 48 & 6.30 & 4.93 & 9.16 \\
\hline 49 & 5.23 & 3.63 & 6.09 \\
\hline 50 & 2.70 & 3.03 & 4.15 \\
\hline 51 & 4.26 & 2.10 & 3.38 \\
\hline 52 & 2.90 & 1.08 & 1.80 \\
\hline
\end{tabular}

Table.2a Co-efficient of Correlation and regression equation of aphid abundance with environmental factors

\begin{tabular}{|c|c|c|}
\hline Parameters & $\begin{array}{c}\text { Co-efficient of } \\
\text { correlation }\end{array}$ & Regression equation \\
\hline \multicolumn{2}{|c|}{ Temperature } \\
\hline Maximum & $0.46(\mathrm{~S})$ & $\mathrm{y}=0.671 \mathrm{x}-10.74$ \\
\hline Minimum & $0.40(\mathrm{NS})$ & $\mathrm{y}=0.341 \mathrm{x}+3.62$ \\
\hline \multicolumn{2}{|c|}{ Relative humidity } & $\mathrm{y}=-0.196 \mathrm{x}+25.9$ \\
\hline Maximum & $-0.23(\mathrm{NS})$ & $\mathrm{y}=0.060 \mathrm{x}+6.42$ \\
\hline Minimum & $0.18(\mathrm{NS})$ & $\mathrm{y}=-0.015 \mathrm{x}+9.90$ \\
\hline Rainfall & $-0.18(\mathrm{NS})$ & \\
\hline
\end{tabular}


Fig.1

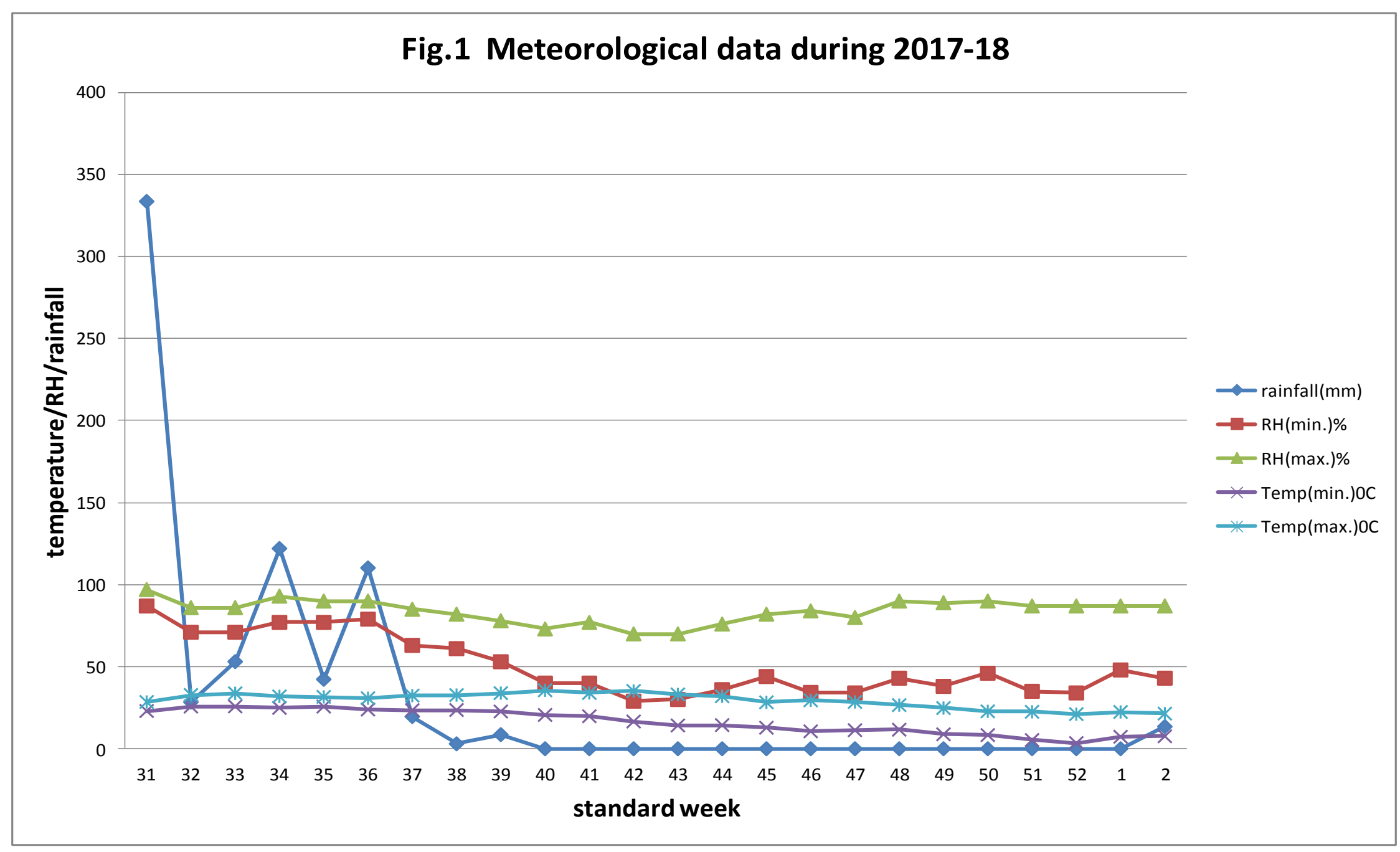


Table.2b Co-efficient of Correlation and regression equation of thrips abundance with environmental factors

\begin{tabular}{|c|c|c|}
\hline Parameters & $\begin{array}{c}\text { Co-efficient of } \\
\text { correlation }\end{array}$ & Regression equation \\
\hline \multicolumn{2}{|c|}{ Temperature } & \\
\hline Maximum & $0.30(\mathrm{NS})$ & $\mathrm{y}=0.216 \mathrm{x}-2.709$ \\
\hline Minimum & $-0.29(\mathrm{NS})$ & $\mathrm{y}=-0.121 \mathrm{x}+5.887$ \\
\hline \multicolumn{2}{|c|}{ Relative humidity } & $\mathrm{y}=-0.335 \mathrm{x}+31.89$ \\
\hline Maximum & $-0.81(\mathrm{NS})$ & $\mathrm{y}=-0.115 \mathrm{x}+9.619$ \\
\hline Minimum & $-0.71(\mathrm{NS})$ & $\mathrm{y}=-0.017 \mathrm{x}+4.301$ \\
\hline Rainfall & $-0.42(\mathrm{NS})$ & \\
\hline
\end{tabular}

Table.2c Co-efficient of Correlation and regression equation of mites abundance with environmental factors

\begin{tabular}{|c|c|c|}
\hline Parameters & Co-efficient of correlation & Regression equation \\
\hline \multicolumn{2}{|c|}{ Temperature } & \\
\hline Maximum & $-0.07(\mathrm{NS})$ & $y=-0.065 x+6.456$ \\
\hline Minimum & $-0.49(\mathrm{~S})$ & $y=-0.249 x+8.739$ \\
\hline \multicolumn{2}{|c|}{ Relative humidity } & \\
\hline Maximum & $-0.45(\mathrm{~S})$ & $y=-0.224 x+23.26$ \\
\hline Minimum & $-0.68(\mathrm{~S})$ & $y=-0.131 x+11.12$ \\
\hline Rainfall & $-0.42(\mathrm{~S})$ & $y=-0.021 x+5.061$ \\
\hline
\end{tabular}

Gopal et al., 2018, recorded significant negative correlation with maximum relative humidity and rainfall. Pathiapal et al., 2014, observed that a negative correlation with minimum temperature, rainfall, morning and evening relative humidity, positive correlation with the maximum temperature.

\section{Mite}

It revealed that all the parameters, maximum and minimum temperature, maximum and minimum relative humidity, rainfall are negatively correlated to the mite population. Maximum temperature is non-significant while all other parameters are statistically significant. Lingeri et al., 1998, studied the mite population was favoured by higher temperature, lower humidity and lesser intensity of rainfall and negative correlation was observed between relative humidity and total rainfall.

\section{References}

Bhede, B. V., Bhosle, B. B. and More, D. G. (2008a). Influence of meteorological factors over the incidence of chilli mite, Polyphagotarsonemus latus and its chemical control strategies. Indian Journal of Plant Protection. 36(2): 200-203.

Bhatt B, Karnatak A K. Population dynamics of sucking pests and their predators on okra agroecosystem. Journal of Entomology and Zoology Studies. 2018; 6(2):1289- 1291.

Butani, D. K. (1976). Pest and diseases of chillies and their control. Pesticides. 9: 38-41. 
Deepak Kumar, S V S Raju and Kamal Ravi Sharma, Journal of Pharmacognosy and Phytochemistry 2019; 8(2): 403407.

Gopal G V, Lakshmi K V, Babu B S, Varma P K. Seasonal incidence of chilli thrips, Scirtothrips dorsalis hood in relation to weather parameters. J Ent., Zool. Stud. 2018; 6(2):466-471

Ghose M, Bhattacharya S, Mandal S K. Seasonal incidence of pests of bell pepper (Capsicum annum var grossum Sendt) and their correlation with weather parameters. Journal of Entomology and Zoology Studies. 2018; 6(3):825-830

Karmakar K. (1995). Comparative symptomology of chilli leaf curl disease and biology of tarsonemid mite, Polyphagotarsonemus latus Banks, (Acari :Tarsonemidae). Annals of Entomology. 13(2): 65-70.

Kumar N K K. Yield loss in chilli and sweet pepper due to Scirtothrips dorsalis Hood. Pest Management in Horticultural Ecosystem. 1995; 1(2):61-69.

Lingeri, M. S., Awaknavar, J. S., Lingappa, S. and Kulkarni, K. A. (1998). Seasonal occurrence of chilli mites (Polyphagotarsonemus latus Banks) and thrips (Scirtothrips dorsalis Hood). Karnataka Journal of Agricultural Science. 11(2): 380-385.

Manjunatha M, Hanchinal S G, Reddy G V P (2001) Survey of yellow mite and thrips on chilli in North Karnataka. Insect Environment 6: 178.

Meena, R. S., Ameta, O. P. and Meena, B. L. (2013). Population dynamics of sucking pests and their correlation with weather parameters in chilli, Capsicum annum L crop. The Bioscan. 8(1):177180.

Patel B H, Koshiya D J, Korat D M (2009) Population dynamics of chillithrips, Scirtothrips dorsalis Hood in relation to weather parameters. Karnataka Journal of Agricultural Sciences 22: 108-110.

Pathipati V L, Vijayalakshmi T, Naidu L N (2014) Seasonal incidence of major insect pests of chilli in relation to weather parameters in Andhra Pradesh. Pest Management in Horticultural Ecosystems 20: 36-40.

Patnaik, N. C., Behera, P. K. and Dash, A. N., 1986, some bio-ecological observations on the chilli thrips, Scirtothrips dorsalis Hood in Orissa. Orissa J. Hort., 14; 25-28.

Rafee C, Havanoor R,. Seasonal incidence of sucking pests of chilli (Capsicum annum L.) and their natural enemies. Entomology and Zoology Studies. 2018; 6(4):1786-1789.

Reddy A A, Narendra R C, Antha K D, Manohar R A, Narebdra R S. Seasonal incidence of thrips and relation to abiotic factors in chilli (Capsicum annun L.), Journal of Entomology and Zoological Studies. 2017; 5(6):304306.

Venkatesh, H M., Muniyappa, V., Ravi, K S and Krishna Prasad, 1998, Management of chilli leaf curl complex, proceedings of First National Symposium on Integrated Pest management (IPM) in Horticultural crops, Bangalore, pp 111-117.

\section{How to cite this article:}

Prathyusha, P., R. K. Dwivedi, Deepak Pal and Gulab. 2021. Studies on Population Dynamics of Sucking Pests Complex of Chilli and their Relation with Environmental Factors. Int.J.Curr.Microbiol.App.Sci. 10(05): 802-808. doi: https://doi.org/10.20546/ijcmas.2021.1005.090 